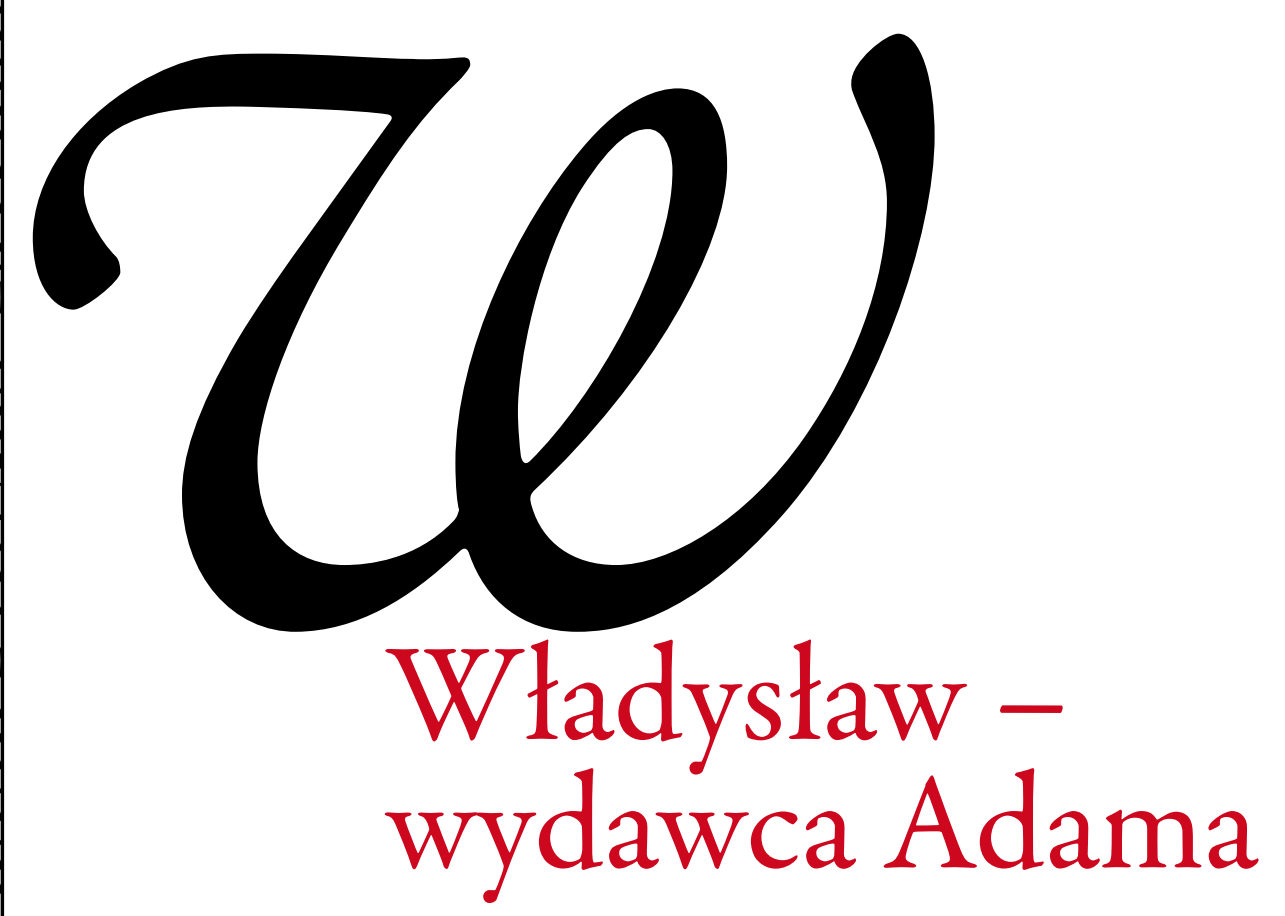

\title{
Alter ego?
}

„[...] z iście religijnym szacunkiem, nie pozwalając sobie na żadną zmianę" - tak ostatnie zdanie wstępu do Historii przysztości wydrukowane w pierwszym tomie Mélanges posthumes z 1872 roku określa sposób, w jaki Władysław Mickiewicz potraktował ojcowski tekst ${ }^{1}$. Choć tak kategoryczne zastrzeżenie zostało wyrażone expressis verbis tylko ten jeden raz w całym tomie, i choć każe nam ono wierzyć, że ze wszystkimi innymi tekstami postępował edytor podobnie, przyjrzyjmy się jednak jego pracy z bliska.

Przypomnijmy pokrótce: Władysław Mickiewicz pragnął pokazać całość dzieła Adama - miało to być jego największe, być może jedyne (w każdym razie jedyne głośno wyrażane i pojmowane w kategorii „misji” i „synowskiego obowiązku”) pragnienie. Założenie tak ambitne, że nie starczyło długiego i pracowitego życia, by mu w pełni sprostać - mimo wyrażanej nadziei na rychłe jego ukończenie ${ }^{2}$. Dzieło pozostało nieukończone, a jego analiza pozwala, jak słusznie zauważył już Mikołaj Sokołowski, dostrzec pewne ambiwalencje stosunku do twórczości ojca oraz wyglądające spoza tekstów biografa i interpretatora pragnienie własnej twórczości ${ }^{3}$. Rozumiejąc swoje zadanie przede wszystkim jako poszukiwanie Prawdy - pisanej przez duże „P” - i uosobionej w twórczości i życiu Adama, Władysław budował jednolity gmach, „doprowadzał do końca” dzieło ojca, ukazując jego całkowitą spójność i harmonię:

Zbliża się pora, w której harmonia tej godnej podziwu egzystencji uwolni się od mglistej atmosfery przyziemnych namiętności. Uważny obserwator powiadał, że najgorszą karą dla niejednego adwersarza byłoby zmuszenie go, by przeczytał swoje ataki w dwadzieścia lat po ich napisaniu. Ileż absurdalnych anegdot, ileż oskarżeń rzucanych w złej 
wierze i którym czas odda sprawiedliwość! Moja publikacja sprostuje krążące nadal błędne opinie ${ }^{4}$.

Syn niezmiennie umieszczał pisma ojca w kontekście twórców największych, najchętniej przywoływał nazwiska Moliera i Szekspira, a z poetów bliższych w czasie - Byrona5. Przechowywanie i udostępnianie dokumentów pozostałych po wielkich pisarzach uważał przy tym za jedno ze swoich najważniejszych zadań:

Kto wie, co stało się z papierami Szekspira, z papierami Moliera? Ich współcześni pozwolili, by poginęły bez śladu. [...] Czy nie jest np. godne pożałowania, że nadal nie wiemy, czy rodzina lorda Byrona nie posiada dwóch niewydanych pieśni Don Juana albo Wspomnień angielskiego poety ${ }^{6}$.

Władysław pragnął tym samym zbudować swój własny obraz wiernego stróża pamięci ojca. Wiemy skądinąd, że obraz ten budował świadomie, dokonując selekcji publikowanych i komentowanych listów i wydarzeń z życia poety:

Adam Mickiewicz był zbyt wielkim patriotą, by odczuwać jakiekolwiek pokusy w Rosji. Otoczony uwodzicielkami, nie musiał nawet ze sobą walczyć. Pozostawił bowiem swoje złudzenia na Litwie ${ }^{7}$.

Z czysto praktycznego punktu widzenia publikacja nieznanych dotychczas ,papierów” niosła natomiast przewagę nad innymi wydawnictwami obecnymi na rynku. Zmaganie się, rywalizacja $\mathrm{z}$ innymi współczesnymi wydawcami, Gubrynowiczem i Schmidtem ze Lwowa czy Brockhausem z Lipska, będzie zaś stałą troską, by nie powiedzieć, kłopotem, Księgarni Luksemburskiej - wydawnictwa „dzieci poety”, jak ją czasami nazywano ${ }^{8}$.

Swój gmach Władysław stawiał na solidnym, bo podwójnym fundamencie: z jednej strony było to życie Adama, z drugiej - idee filozoficzne, polityczne, historiozoficzne, jakim sam hołdował. We współczesnych mu wydarzeniach syn doszukiwał się spełnienia proroctw zawartych w pismach ojca, albo choć zapowiedzi ich spełnienia ${ }^{9}$. Ta prorocka, historyczna i religijna zarazem Prawda była bowiem dla niego właściwą raison d'être mickiewiczowskiego pisarstwa i - geniuszu. Udało mu się doprawdy zbudować konstrukcję wiarygodną - wszelkie jego poczynania przez długie lata traktowano przecież w polskiej nauce o literaturze jako wyraz całkowitej wierności twórczości wielkiego ojca, a samego Władysława niemal jako jego alter ego - kończącego pracę, której nie zdołał za życia wykonać Adam ${ }^{10}$.

Władysław chciał przekonać zarówno pierwsze pokolenie badaczy twórczości Adama, jak i współczesnych mu czytelników, polskich oraz francuskich ${ }^{11}$. Zwracał się przy tym do doskonale znanego mu czytelnika - o ukształtowanych gustach literackich, o ustalonych przyzwyczajeniach językowych, o łatwych do określenia przekonaniach religijnych, społecznych, nawet politycznych. Szczególnego znaczenia nabierają tutaj teksty francuskie, w znakomitej większości wydane po raz pierwszy. Te, które ukazały się wcześniej, w trudno dostępnych już po przeszło półwieczu paryskich czasopismach, również zebrano w dwóch nowych tomach. O francuszczyźnie ojca Władysław miał wysokie mniemanie - tak przynajmniej deklarował:

Tych kilka stron zdradza głęboką znajomość języka francuskiego, jego najdrobniejszych odcieni, jaką posiadał Adam Mickiewicz. Daje on tu przykład, co można wydobyć z języka francuskiego, tylekroć oczernianego. Przyznać trzeba, że gdyby Adam Mickiewicz był Francuzem, ukazałby, że język francuski potrafi w poezji olśnić tym samym bogactwem wyrazu, które podziwiamy w jego dziełach napisanych po polsku ${ }^{12}$.

Teksty te zostały opublikowane późno i w czasie, gdy Księgarnia Luksemburska zmagała się z największymi finansowymi trudnościami. Czyżby próba zainteresowania, pozyskania francuskojęzycznego czytelnika była zarazem próbą poprawy kondycji wydawnictwa? ${ }^{13}$ Nawet jeśli tak było, nie oznacza to drukowania pospiesznego czy mniej starannego. Wszystkie teksty, pierwodruki i przedruki, utwory tłumaczone na francuski i po francusku napisane w oryginale, zostały obudowane szeroko zakrojoną kontekstualizacją. Sięga ona nie tylko do historii życia ich twórcy, ale i, a może przede wszystkim, do współczesnych wydawcy teorii społecznych i politycznych, do aktualnych wydarzeń. Piszę tu „przede wszystkim”, gdyż francuskich tekstów Władysław nie zdecydował się umieścić w ramach, budowanej przecież przez siebie i przyjętej potem przez mickiewiczologów, periodyzacji życia poety. Może tu pojawić się pytanie, czy wątpliwość, na ile utwory te miały stanowić w oczach Władysława zespół niejako osobny, na ile zaś, być może, były jedynie pretekstem, okazją, by dać wyraz własnym teoriom politycznym i społecznym. Teorii, przypomnijmy od razu, mających służyć objawianiu, przejawianiu się mickiewiczowskiej Prawdy.

\section{Polski wieszcz francuskim humorystą?}

Drobne francuskie teksty Mickiewicza są doprawdy szczególne z jednej strony dostęp do nich francuskiego czytelnika powinien być łatwiejszy, jako że nie wymagał zapośredniczenia przekładu, z drugiej - opublikowane stosunkowo późno (drugi tom Mélanges 
ukazał się w 1879 roku, nakładem tej samej Księgarni Luksemburskiej, tekst Rozmów chorych znalazł się zaś dopiero w Żywocie opublikowanym w 1895 roku), nie zdołały „na czas” wejść do czytelniczej świadomości. Pod wydawniczym piórem Władysława teksty te nabierają jednak niemałego znaczenia: „Niech Bóg mnie strzeże, bym odmawiał znaczenia tym literackim okruchom!"14. Powstawały one przy tym na przestrzeni niemal całego twórczego życia poety - od roku 1827 po tragiczny listopad 1855. Między petersburską gorzką humoreską a stambulskim szkicem mającym za temat chorych na cholerę wiarusów mieszczą się artykuły interwencyjno-historyczne (na temat zniszczonych polskich bibliotek, zamówiony do Encyklopedii katolickiej żywot św. Wojciecha), krytycznolite-

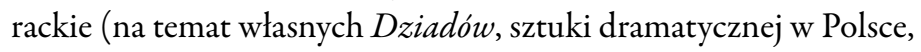
twórczości Goethego i Byrona, współczesnego niemieckiego malarstwa, poezji rosyjskiej - przy okazji wspomnienia-nekrologu Aleksandra Puszkina) czy literackie (dwuznaczny Tydzień miodowy rekruta, niepokojąca do dzisiaj Historia przysztości).

Władysław-wydawca nie zadowala się wyłącznie udostępnianiem tekstów w druku czytającej publiczności. Równie ważna jest ich interpretacja ideologiczna i historiozoficzna, historyczna i religijna. Teksty literackie są bowiem dla Władysława „dokumentami”, faktami w takim samym stopniu, jak dokumenty polityki międzynarodowej i krajowej czy prasowe doniesienia. Nie interesują go interpretacje, jakie mogą wyniknąć z uważnego czytania „nagiego” tekstu. Pytań tych nawet nie odrzuca czy nie pozostawia na później - on po prostu ich sobie nie stawia ${ }^{15}$. Potwierdzenia swoich teoretycznych, interpretacyjnych stwierdzeń szuka najczęściej w paryskich kursach z Collège de France i w ojcowskiej korespondencji, z której nierzadko przytacza obszerne fragmenty.

Nie oznacza to bynajmniej, że rękopisy czyta pobieżnie wręcz przeciwnie. Porównanie zestawienia odmian pierwodruków i autografów dowodzi zwykle licznych, nierzadko poważnych modyfikacji tych ostatnich, ingerencji wręcz w samą tkankę tekstu napisanego ręką poety. Jak je pogodzić z przywołanym na wstępie zastrzeżeniem o dochowaniu wierności dziełu ojca i wysoką oceną francuszczyzny Adama? Czy Władysław pozostaje tu nadal jedynie przekazicielem tej twórczości? Na ile budowanie obrazu całościowego, a także ingerowanie w sam tekst już je s t jego interpretacją, przekazywaniem takiej wersji, jaką uważał (w dobrej wierze i zgodnie z własnymi przekonaniami) za stosowną: „Chociaż nie rozpoczęliśmy jeszcze [pisania] biografii Adama Mickiewicza, mamy nadzieję, że ułatwi ona badania nad największym poetą Słowian. Nie śmiemy, oczywiście, sądzić, że rozpowszechnienie jego pisanych po polsku dzieł dokona się we Francji w ciągu jednego dnia" ${ }^{16}$.

Odnosimy wrażenie, że edytor pragnął z jednej strony „wygodnie” usadowić każdy utwór na poziomie samego tekstu, zapew- niając mu ortograficzną, interpunkcyjną, gramatyczną i syntaktyczną poprawność. Z drugiej - wpisywał go w ramy ideologicznej, uwiarygodniającej „przynależności”. O tym, że jest to działanie celowe i przemyślane, świadczy żelazna konsekwencja, z jaką prowadzone są te wydawnicze poczynania.

Zanim przyjdzie pora na ukazanie całości prac redaktorsko-interpretacyjnych Władysława Mickiewicza związanych z drobnymi francuskimi tekstami Adama, warto przedstawić chociaż próbkę jego postępowania. Niech posłuży nam za przykład najwcześniejszy, znany nam dzisiaj, francuski tekst Adama Mickiewicza ${ }^{17}$.

\section{Po francusku w Rosji}

W 1827 roku w Rosji Adam Mickiewicz napisał krótkie opowiadanie - w liczącym sześć stronic i sto linii rękopisie pozostało ono bez tytułu ${ }^{18}$. W dotychczasowej tradycji edytorskiej zwykło się je określać Mitość poety a mitość fllozofa lub, za pierwodrukiem w drugim tomie Mélanges z 1879 roku, gdzie nosi tytuł Ce que ferme préfère - Co kobieta woli ${ }^{19}$. Tekst, będący jakby Gogolowskim Ożenkiem - in nucleo, jest dialogiem panny na wydaniu i jej pokojówki. Tak Władysław definiuje tekst AdaDrobne francuskie
teksty Mickiewicza są
doprawdy szczególne ma we wstępie:

Adam Mickiewicz, jak zobaczymy, w bardzo przyjemny sposób naśmiewał się z małżeństwa z rozsądku. W przenikliwy sposób ośmieszył (a jest to, skądinąd, najstraszliwsza broń przeciw osobom z towarzystwa) tych, którzy ukrywając prozę swojej duszy pod konwencjonalnym sentymentalizmem, wydają się przeżywać miłość doskonałą, wznoszą oczy ku niebu, na ich wargach goszczą najbardziej poetyckie słowa, lubują się w rozmowie o filozofii, a w rzeczywistości kochają jedynie złoto i wszystko, co prowadzi ku wygodnemu życiu ${ }^{20}$.

Panna roztrząsa zalety i wady kandydatów, bodaj siedmiokrotnie zmienia zdanie, pokojówka nieodmiennie przytakuje swojej pani. Tekst kończy się ironicznym autorskim komentarzem na temat natury miłości poetów i filozofów oraz jednoznacznym określeniem przymiotu, który jako jedyny zapewnia szczęśliwe małżeństwo:

Niech więc damy zadecydują, kogo wolą, poetę czy filozofa. Ja, z uszanowaniem dla jednych i drugich, jestem za horodniczym Borysem, o ile tylko ma trzypiętrową kamienicę oraz 20 tysięcy rubli i 40 kopiejek czystego dochodu ${ }^{21}$.

Stwierdzenie to staje się punktem wyjścia obszernego, bo liczącego czternaście stron druku, wydawniczego komentarza. Małżeń- 
stwo zawierane bez miłości, tzw. małżeństwo z rozsądku, nazwał komentator „plagą” swoich czasów ${ }^{22}$. „Kiedy [Mickiewicz] napisał [ten tekst], wyprzedzał swoją epokę, obecnie jego dzieło jest jak najbardziej na czasie" - czytamy ${ }^{23}$. Ujawniają się więc również i tutaj prorocze zdolności Mickiewicza. Tekst literacki służy ilustrowaniu faktu społecznego, a Władysław potrafi wydobyć wiele jego aspektów. Przede wszystkim ocenianie ludzi z uwagi na posiadany majątek: mężczyzn - ich "pozycję”, kobiet - posag. "Jedynie pieniądze stanowią o człowieku, jeśli jest ubogi - jeszcze nie istnieje, jeśli jest zrujnowany - już go nie ma”. Mężczyzna zdolny do małżeństwa - czyli majętny - siłą rzeczy nie jest najmłodszy, a że małżeński „rynek” wymaga od kandydatki, by była młoda, niewinna i traktuje ją niczym własność mężczyzny - więc „kiedy on kończy swoje życie, ona je zaczyna" ${ }^{24}$. Prowadzi to do nieuchronnych konfliktów, a uciekanie się do nieustannych rozrywek zdaje się drogą ich łagodzenia. Nadmierne dążenie do zbytku jest jednak zarazem przejawem dekadencji pojawia się porównanie z ginącą cywilizacją starożytnego Rzymu (motyw, jak wiemy skądinąd, drogi romantykom!) - „czy Barbarzyńcy stoją już u naszych drzwi ?” - pyta, nieco dramatycznie, Władysław $^{25}$. Kościół nie powinien błogosławić małżeństw „z rozsądku”, gdyż nie sposób mówić o związku dwojga ludzi, których dusze nie połączyły się uprzednio w niebie - tzn. nie związały węzłem miłości - oto kolejne, żywe pod piórem Władysława, pojęcie właściwe dla romantyzmu ${ }^{26}$. Francuska burżuazja jest tutaj oskarżana o rozsiewanie zła w całej Europie. Jej postawa to „trucizna wąskiego egoizmu, zaraza głupoty”27, a wyjście to „odrodzenie”, które może przyjść tylko przez kobiety - takie, które nie będą pragnęły już mężów bogatych, lecz „uczciwych patriotów” („kiedy Francuzka będzie wolała mieć za męża patriotę ubogiego, ale uczciwego, zdolnego i pełnego entuzjazmu, od głupiego i tchórzliwego, choć bogatego, rentiera i bezwzględnego spekulanta, albo od człowieka z tytułami, lecz nic niewartego ignoranta, albo od człowieka z dyplomami, ale służalczego, być może świetnego urzędnika, ale gotowego oddawać usługi obojętnie komu, choćby i obcym” ${ }^{28}$. Tymczasem jednak dla ówczesnych panien nie było alternatywy dla małżeństwa, a presja środowiska pozostawała przemożna, czego Władysław zdaje się jednak nie dostrzegać. Bo jeśli panny i panie tamtego czasu tak znakomicie znały się na wstążkach, co zdaje się im wyrzucać nasz redaktor, to pamiętajmy, że działo się tak również, a może przede wszystkim, dlatego, że nie dawano im możliwości poznania się na czym innym, że droga do życia zawodowego była przed nimi zamknięta, a nierówność w stosunku do prawa skazywała na uciekanie się w życiu codziennym do rozmaitych wybiegów. Tej podstawowej niesprawiedliwości nasz autor jednak najwyraźniej nie zauważa, a o emancypacyjnych postulatach i poglądach swego ojca - nie pamięta ${ }^{29}$. Pamięta natomiast niezmiennie o wyjątkowej roli Polski także i w tym względzie:

To zło, wprawdzie mniej rozpowszechnione wśród Polaków, niż wśród większości innych narodów, istnieje również pośród nich. I muszą je oni zwalczać z tym większym staraniem, jako że ich misja jest wyższa i sprawa, jaką będą musieli zdać przed Opatrznością będzie surowiej oceniana ${ }^{30}$.

Zjawisko społeczne znajduje też swoje literackie odniesienia: „małżeństwo bez miłości jest równie absurdalne, jak filozoficzna poezja” - czytamy, zaś w następujących po tekście przypisach czytelnik znajdzie prawdziwą rozprawkę na temat literackich przedstawień współczesnego małżeństwa. Poczesne miejsce zajmują tu powieści Honoré de Balzaca, a szczególnie jego Fizjologia matżeństwa: stosunki, które w małżeństwie prowadzą do zdrady, w państwie prowadzą do zdrady stanu, a miłość w starszym wieku jest nie tylko niestosowna, ale wręcz przeciwna naturze...

Drugim aspektem, wiążącym się z Mickiewiczowskim tekstem, obśmiewającym zarówno konwencjonalne pozory romantycznego uczucia, jak i modę na pisanie wierszy i powszechne pragnienie ich drukowania, jest stosunek poetów czy, szerzej, literatów do pieniędzy. Nie tylko Adam, „nawet jako mężczyzna żonaty nigdy nie nawrócił się na czysty dochód"31, również Władysław surowo ocenia rezultat bliższych „związków” pisarzy z zarobkowa-

\section{Władysław zdradza zacięcie krytyka i historyka literatury}

niem. Czytamy zatem:

Sądzę, że kiedy tylko poezja zacznie przynosić złoto, przekształci się stopniowo w uwielbienie złota i zniknie, jak każde bałwochwalstwo. Kiedy [pisarze] tworzyć będą dla złota, nie zdołają zasłużyć sobie ani na chwałę, ani na złoto. Opieka królów i panów była stukrotnie mniej niebezpieczna, niż opieka księgarzy i dziennikarzy. Epoka, w której dominuje zainteresowanie dla zarobku, o ile jest najszczęśliwsza dla literatów, dla literatury najszczęśliwsza nie jest ${ }^{32}$.

W przypisach Władysław przytacza obszerne fragmenty artykułu omawiającego szczegółowo dochody pisarzy francuskich XIX wieku: François-René de Chateaubrianda, Balzaca, Aleksandra Dumasa, Victora Hugo, Alfreda de Vigny, i mniej znanych - Jules'a Janina i Féliciena Mallefille’a. Widzimy, że Władysław jest zainteresowany współczesnym mu życiem intelektualnym i literackim Francji, czuje się także jego uczestnikiem, przytacza najnowsze publikacje (jak choćby Souvenirs sur Teophile Gautier Ernesta Feydeau z 1872 roku). Ujawnia też pisarski i publicystyczny „pazur” wyraża własne opinie, potrafi cytować zarówno Orlanda Szalonego Lodovica Ariosta, jak i wiersze Alfreda de Musseta. Wszystkie cytaty są opatrzone pełną informacją bibliograficzną na temat źródła, z jakiego nasz komentator czerpał. Fragmenty te pokazują ponadto, jak żywo interesował się ówczesną polityką i życiem społecznym Francji ${ }^{33}$. Zainteresowanie to nie było bynajmniej wyjątko- 
we - przy innych okazjach nawiązywał do dyskusji o przyczynach klęski w wojnie z Prusami czy do toczącej się wówczas debaty nad wprowadzeniem powszechnego świeckiego nauczania ${ }^{34}$.

Warto wspomnieć jeszcze o bogatym i interesującym aparacie przypisów, które następują po tekście literackim - w naszym przypadku zajmuje on całych szesnaście stron. Wiele tematów staje się pretekstem do prawdziwych rozprawek, jak wspomniane już kwestie finansowe związane z uprawianiem literatury. Szczególnym miniesejem stał się przypis na temat Francesco Petrarki. Tutaj Władysław zdradza zacięcie krytyka i historyka literatury, wspiera się nazwiskami znanych ówcześnie autorytetów (m.in. Edgara Quineta) i choć wiele z jego tez nie znajduje potwierdzenia w dzisiejszej wiedzy o literaturze, to jego kompetencji jako interpretatora zaprzeczyć nie sposób ${ }^{35}$. Wspomnijmy jeszcze o innych literackich odniesieniach: rozmowie na temat pożytków z małżeństwa niezdecydowanego Pantagruela z dziewiątego rozdziału opowieści François Rabelais'ego, opowiastce Jonathana Swifta o filozoficznej miotle, tożsamości ukochanej Owidiusza, roli Ksantypy w życiu Sokratesa. Wyjaśnione są też elementy rosyjskiej rzeczywistości: podana wartość rubla, moskiewska ulica Twerska porównana do eleganckiego Boulevard des Italiens w Paryżu, określone kompetencje isprawnika, przetłumaczone słowa rosyjskiej piosenki i imiona kandydatów na męża.

Wydawca wyjaśnia też rolę zwrotów grzecznościowych „tu” i „vous”, rzeczy tak bardzo istotnej dla liczących się z towarzyską konwencją francuskich czytelników. Dotyka tutaj kwestii językowej, która jego czytelnikom może wydać się kontrowersyjna - nie ingeruje jednak w sam tekst, lecz tłumaczy prawdopodobne przyczyny takiego „językowego” zachowania autora. Najczęściej jednak stosunek wydawcy do tekstu jest zgoła inny i modyfikacje pierwodruku w stosunku do autografu są liczne - jest ich dziewięćdziesiąt sześć na sto linii tekstu. Wydają się całkowicie usprawiedliwione, gdy porządkują tekst - szczególnie taki, który nie był nigdy przygotowywany do druku, który został zarzucony i pozostaje w formie niedokończonej (jak np. Historia przysztości czy Rozmowy chorych). Mamy wówczas do czynienia $\mathrm{z}$ ustaleniami ortografii, z niezbędnymi unowocześnieniami archaicznej pisowni Adama (interesujące jest, na ile była ona archaiczna już wtedy, gdy teksty te były pisane $)^{36}$. Są to też, naturalnie, systematycznie dopisane akcenty, praktycznie nieobecne zresztą w autografach zdradzających pospieszny proces zapisywania myśli twórczej, poprawione drobne omyłki - takie jak brakujące litery czy przestawiona ich kolejność w słowie. Jest to ustalanie interpunkcji (jakże jednak nieobojętnej dla wymowy tekstu literackiego!) ${ }^{37}$. Obok porządkowania form czasownikowych, tak by orzeczenie było zgodne z liczbą i rodzajem podmiotu, obok uzupełnienia niezbędnych czasowników posiłkowych w czasach zło- żonych i dbałości o zgodność rodzaju i liczby orzeczenia, podmiotu i jego przydawek, spotykamy się jednak i z ingerencjami sięgającymi dużo głębiej.

Są to przede wszystkim modyfikacje słownictwa, idące zwykle w kierunku „wydźwignięcia” tekstu na wyższy poziom stylistyczny, pragnące dostosować go do normy pisanej, literackiej francuszczyzny. Tak więc w miejscu, gdzie poeta pisze „fille” („dziewczyna”), mamy „dame” („dama”) lub „jeune fille” (poprawniej - „dziewczyna”, „panna”), „rougirent” zastąpiły „teignirent” (policzki konkurującego o rękę bohaterki filozofa nie „czerwienią się” już po prostu, a „malują”, czy „barwią na różowo”, „appellé” zastąpiło „nommé” („nazwać” - „mianować”), „revêtir” - „prendre” („przybrać” „wziąć”), „naguère” - ,jadis” („niegdys'” - „kiedys'”), „toilettes” „habits” („toalety”, „stroje” - „ubrania”) itp. ${ }^{38}$ Często zmianom ulega też szyk zdania, ponadto redaktor podkreśla z większą siłą stwierdzenia (lub przeczenia) autora ${ }^{39}$. Największe modyfikacje pojawiają się jednak tam, gdzie wydawca opisuje „swoimi słowami” czynności, które uznał za niewystarczająco precyzyjnie określone przez autora. Opowiada zatem, w jaki sposób niecierpliwy poeta przecina palcami stronice wilgotnych jeszcze od farby drukarskiej kart czasopisma, jak śp. mąż garderobianej budził ją do życia z rze-
komego omdlenia wydmuchiwanym przez papierową tutkę dymem, czy jaką to ogromną wadą jest rozrzutność ${ }^{40}$. Redaktor zadbał też o konsekwentne występowanie w tekście form czasu przeszłego historycznego passé simple. Reguła ta francuskim uczniom jest zresztą wpajana w szkołach po dziś dzień.

Zestawienie odmian dowodzi, że pragnienie eliminacji pewnej chropowatości stylu, czasem nieporęczności sformułowań, było nieustannie obecne w zamierzeniach wydawcy i konsekwentnie wcielane w życie. Takie postępowanie pozbawia jednak równocześnie tekst rysów indywidualnych. Do sprawiedliwej oceny pracy Władysława jest wcześniej potrzebna sprawiedliwa ocena językowej kompetencji Adama. Mickiewicz francuski znał dobrze, podobnie jak wszyscy ówcześni wykształceni Polacy (nie tak może dobrze jak Krasiński, który, gdyby tylko chciał, mógłby zostać świetnym francuskim pisarzem). Jednakże dzięki swojej naturalnej łatwości w posługiwaniu się językiem, wyczuciu stylu, wyjątkowej umiejętności kształtowania różnych poziomów wypowiedzi, także francuszczyznę potrafił naginać do swoich potrzeb. Zdaje się to doceniać Władysław, kiedy pisze, że poeta potrafił „wystarczająco rozłożyć [swe] orle skrzydła, by móc poruszać się i w ciaśniejszej przestrzeni" ${ }^{41}$.

To Adam kształtował swoją francuską prozę, nie pozwalał „unosić się” na jej pozornie kojących, łagodnych falach. Władysław natomiast mieszkał we Francji od urodzenia i choć wychowany w środowisku polskim i, tu nie mamy najmniejszych wątpliwości, w poczuciu polskiej przynależności, to chodził przecież do fran- 
cuskiej szkoły. Opanował doskonale wszystkie kulturowe „kody” francuszczyzny, szczególnie w tej najtrudniejszej dla przybyszów, pisanej odmianie. Zdawał sobie z nich sprawę, pozostając równocześnie „na zewnątrz” (kiedy wspomina chociażby o francuskiej mentalności wysoko ceniącej konwencje i przelotną modę) $)^{42} \mathrm{i}$,wewnątrz" (kiedy zabiera głos we wspominanych już francuskich debatach ${ }^{43}$. Kierując edycje do wykształconego przecież czytelnika, nie chciał i nie mógł ryzykować prezentowania mu tekstu obarczonego najmniejszą niepoprawnością czy wahnięciem normy.

W wyniku takich zabiegów oryginalny tekst traci tę skrótowość, celność krótkiego zdania, dosadność wyrażeń, bliskość językowi mówionemu, które charakteryzują francuskojęzyczne literackie teksty naszego poety - prozatora. Pozbawia go to cech świeżości i autentyczności, które sprawiają, że Mickiewiczowska proza jest bliska prozie nowoczesnej, zgodnej z normą pisanej francuszczyzny epoki, co nieuchronnie prowadzi w kierunku językowego banału.

We wstępie do przywoływanych tu już po wielokroć Mélanges posthumes d'Adam Mickiewicz z 1872 roku, Władysław Mickiewicz cytuje słowa ojca z 1847 roku:

Mógłbym zrobić tu wspaniałą karierę, pod warunkiem odrzucenia zasad, jakimi kieruję się w życiu, i gdybym uspoko ił s i ę. Odpoczynek przystoi chorym i szczęśliwym. Nie możemy sami nie być niespokojnymi, a naszym obowiązkiem jest niepokoić świat. Będę więc nadal szedł moją drogą, z nadzieją, że zawsze znajdę ludzi dobrej woli, gdyż wszyscy oni mają jeden $\operatorname{cel}^{44}$.

Wydaje się, że rozpoznaje się w nich sam redaktor, że kierowały one także jego pracą. Równocześnie inicjatywa Władysława Mickiewicza była jedyną, musimy mieć tego świadomość, wydawniczą realizacją, w której drobne teksty francuskie znalazły swoje miejsce w druku. Jedyną po dzień dzisiejszy. Postulowana przezeń krytyczna edycja całości dzieła Adama nadal nie doszła do skutku. Bojąc się zboczyć z drogi, zapaść w ruchomych piaskach pokreślonych autografów, kroczymy może zbyt wiernie po zbyt świeżych jeszcze śladach Władysława...

${ }^{1}$ Mélanges posthumes d'Adam Mickiewicz, publiés avec introduction, préfaces et notes par L. Mickiewicz, première série, Vol. 1, Paris 1872, s. 160: "Nous n'avons pas besoin de dire que nous l'avons religieusement imprimé, sans nous permettre aucun changement".

2 Ibidem, s. III: "La mission d'élever à Adam Mickiewicz la plus durable des monuments, c'est-à-dire de reconstituer l'ensemble de ses travaux, est bien près d'être remplie. Plusieurs volumes se succèderont rapidement qui, joint aux volumes déjà parus, satisferont à ce devoir filial".

${ }^{3}$ M. Sokołowski, Władysław, syn Adama, w: Chrześcijańskie dziedzictwo duchowe narodów słowiańskich. Wokół kultur śródziemnomorskich, t. 1: Literatura i słowo, red. Z. Abramowicz, J. Ławski, Białystok 2009, s. 234-236.
4 "L'heure approche où l'admirable unité de cette existence se dégagera de l'atmosphère brumeuse des petite passions du jour. Un observateur profond disait que la meilleure punition de plus d'un adversaire, ce serait de le forcer à relire ses attaques vingt ans après les avoir produites. Que d'anecdotes absurdes, d'accusations sans bonne foi dont le temps a déjà fait justice! La publication actuelle rectifiera ce qui reste d'erreurs en circulation"; Mélanges posthumes d'Adam Mickiewicz, Vol. 1, s. VII.

${ }^{5}$ Sam napisał: „Tym sposobem zostałem z m u s z o n y [podkr. - J. P.-T.] do wyrażania sądu o faktach i ludziach”; W. Mickiewicz, Żywot Adama Mickiewicza podług zebranych przez siebie materiałów oraz z własnych wspomnień, t. 1, Poznań 1890, s. V; Mélanges posthumes d'Adam Mickiewicz, Vol. 1, s. XX-XXI.

"Qui sait ce que sont devenus les papiers de Shakespeare, les papiers de Molière? les contemporains les ont laissés se perdre, sans qu'il en soit resté de traces. [...] N'est-il pas affligeant, par exemple, qu'on ne sache encore aujourd'hui si la famille de lord Byron ne possède pas deux chants de Don Juan inédis et les Mémoires du poète anglais, dépôt sacré que Thomas Moore aurait faussement affirmé avoir brûlé, malgré la volonté expresse de l'auteur que ce fût publié?"; Mélanges posthumes d'Adam Mickiewicz, Vol. 1, s. I-II.

7 "Adam Mickiewicz était trop patriote pour éprouver une tentation en Russie. Entouré de séduction, il n'eut pas même à lutter contre lui-même. II avit laissé ses illusions en Lithuanie"; Mélanges posthumes d'Adam Mickiewicz, Vol. 2, Paris 1879, s. 89. Na przykład kiedy z góry ucina ewentualne spekulacje na temat osobistych motywacji dla powstania opowiastki Ce que femme préfère.

${ }^{8}$ A. Kłossowski, Ambasador książki polskiej w Paryżu. Władysław Mickiewicz, Wrocław 1971, s. 227-231.

M. Sokołowski, op. cit., s. 238-240.

${ }^{10}$ Ibidem, s. 235 i 242

1 Ibidem, s. 248-249. Na temat wysokości nakładów ówczesnych wydań, trudności w organizowaniu dystrybucji i długotrwałości istnienia książek na rynku księgarskim zob. T. Syga, Te księgi proste, Warszawa 1956, s. 247-267.

2 "Ce quelques pages dénotent chez Adam Mickiewicz une profonde connaissance de la langue française, de ses nuances les plus fines. [...] Adam Mickiewicz [...] donne ici un exemple de ce que l'on peut tirer de la langue française calomniée. On peut affirmer [...] que si Adam Mickiewicz fût né Français, on aurait vu la langue française briller dans ses poèmes des mêmes richesses d'expression qu'on admire dans ceux qu'il a écrits en langue polonaise"; Mélanges posthumes d'Adam Mickiewicz, Vol. 1, s. 148.

${ }^{13} \mathrm{~A}$. Kłossowski, op. cit., s. 227-231.

14 "Dieu me garde de vouloir outrer l'importance de simples bribes littéraires!"; Mélanges posthumes d'Adam Mickiewicz, Vol. 2, s. 62

${ }^{15}$ Ibidem, s. 244.

16 "Bien que nous n'ayons qu'effleuré la biographie d'Adam Mickiewicz, nous espèrons que cela facilitera l'étude de plus grand poète des Slaves. Nous sommes loin de nous imaginer que la vulgarisation en France de ces créations polonaises soit l'oeuvre d'un jour"; Mélanges posthumes d'Adam Mickiewicz, Vol. 1, s. XX. Pierwsze wydanie poezii Mickiewicza (edycja w opracowaniu Leonarda Chodźki) pojawiło się we Francji już w 1828 roku. Od tego czasu jego nazwisko było stale obecne na francuskim rynku księgarskim; T. Syga, op. cit., s. 63 in.

7 J. Pietrzak-Thébault, „Rozmowy chorych” Adama Mickiewicza we francuskim autografie, „Pamiętnik Literacki” 2005, z. 4, s. 185-191. Sygnalizuję tam około trzydziestu ingerencji wydawcy w tekst autografu, który liczy zaledwie dwie strony. Obok ingerencji „poprawnościowych" edytor kilkakrotnie zmienia stylistykę utworu: „gamin” $\rightarrow$ „garçon”; „ça”, „c'est” $\rightarrow$ „cela”, „mirer” $\rightarrow$ „voir”; , "qui est un chef toujours gai” $\rightarrow$ „pour être toujours gai”; , „mon colonnel, mon colonnel” $\rightarrow$ „eh bien comment”.

${ }^{18}$ Autograf przechowuje Biblioteka Polska w Paryżu, nr kat. 6/akc.11.50, liczy on osiem stron, w tym siódma i ósma są niezapisane. Kartki mają wymiary $20,5 \times 17,5 \mathrm{~cm}$. Mikrofilm znajdujący się w Bibliotece Narodowej w Warszawie nosi sygnaturę 78776. Władysław natomiast okoliczności jego powstania sytuuje w Moskwie, w roku 1826; Mélanges posthumes d'Adam Mickiewicz, Vol. 2, s. 69-70. Władysław stanowczo wyklucza wszelkie możliwe autobiograficzne motywy powstania humoreski.

${ }^{19} \mathrm{Na}$ język polski tekst był tłumaczony killkakrotnie - przez Leonarda Rettla w 1880 roku, Józefa Kallenbacha w 1911 roku, w wydaniu w Brodach i wreszcie Artura Górskiego w siódmym tomie Wydania Sejmowego (1936). Ten ostatni przekład został oparty nie na pierwodruku, a na autografie i przedrukowano go następnie w Wydaniu Narodowym, Wydaniu Jubileuszowym (1955) i Wydaniu Rocznicowym (1997).

20 "Adam Mickiewicz s'est, on le verra, agréablement moqué du mariage de raison. Il a fînement tourné en ridicule (or, c'est contre les gens du monde l'arme la plus terrible) ces personnes qui, cachant la prose de leur âme sous le sentimentalsme de convention, ont l'air de ne vouloir que filer le parfait amour, lèvent les yeux au ciel, ont les mots les plus poétiques sur les lèvres, se plaisent à parler philosophie, et, somme toute, n'aiment que l'or et ce qui procure le bien-être"; Mélenages posthumes d'Adam Mickiewicz, Vol. 2, s. 60.

${ }^{21} \mathrm{~J}$. Pietrzak-Thébault, „Quelle difference $y$-a-t-il entre l'amour d'un philosophe et d'un poète” Adama Mickiewicza. Edycja, zestawienie odmian, przekład polski, „Krymsko-Polskie 
Zeszyty Naukowe" 2008, t. 7, s. 53-64 (faktycznie wydanie ukazało się w 2010 roku, już po powstaniu tego tekstu).

22 "La plaie du siècle est le mariage sans amour"; Mélanges posthumes d'Adam Mickiewicz, Vol. 2, s. 57.

23 "Quand il l'a composé, il devançait son époque, maintenant on trouve son oeuvre à son heure"; ibidem, s. 70 .

24 "L'argent, c'est tout l'homme, s'il est pauvre, il n'existe pas encore, s'il esr ruiné,

il n'existe plus"; ibidem, s. 59.

25 "[...] les Barbares sont-ils à nos portes?"; ibidem, s. 58

${ }^{26}$ Ibidem, S. 83.

27 "[... la poison de l'étroit égoisme, la contagion de sa sottise"; ibidem, s. 60

28 "[...] quand la femme française préférera pour mari un patriote pauvre, mais intègre, capable et enthousiaste, à un rentier sot et lâche, spéculard à outrance, mais riche, ou à un être titré mais ignorant et nul, diplômé mais servile, fonctionnaire exact peut-être, mais intrépidement prêt à fonctionner à profit de n'importe que, fût-ce l'étranger"; ibidem, s. 63 .

${ }^{29}$ Obie córki Adama, a siostry Władysława, chodziły do postępowej, by nie rzec awangardowej na owe czasy, paryskiej pensji Josephine Bachellery (kierowała nią od 1839 roku). Powiązana z utopijnymi socjalistami była ona reformatorką edukacji dziewcząt. Dążyła także do utworzenia wyższej szkoły dostępnej dla kobiet, w 1848 roku przedstawiła jej projekt ministrowi Carnot. Opublikowała książkę Lettres sur l'éducation des femmes (Paris 1848); F. Mayeur, Histoire générale de l'enseignement et de l'éducation en France. III: De la Révolution à l'école républicaine (1789-1930), Paris 1981; eadem, L'éducation des filles en France au XIXe siècle, Paris 1979

30 "Le mal, quoique moins grand chez les Polonais que chez la plupart des autres peuples, existe cependant chez eux aussi; et ils se doivent à eux-mêmes de le combattre avec d'autant plus de soin que leur mission est plus élevée et que le compte, qui leur sera demandé par la Providence, sera plus rigoureux"; Mélanges posthumes d'Adam Mickiewicz, Vol. 2, notes, s. 83.

31 "Même marié il ne s'est pas converti au revenu net"; ibidem, s. 68.

32 "Et je pense que, dès que la poèsie rapportera de l'or, elle se métamorphosera peu à peu en idôlatrie de l'or et disparaitra domme toute idôlatrie"; "Quand ils écriront pour de l'or, ils finiront par ne mériter ni gloire ni or. Le protectorat des rois et des seigneurs était cent fois moins dangereux pour la poèsie que le protectorat des libraires et des jornalistes"; "L'époque où domine la préoccupation de gain, si elle est la plus heureuse pour les littératuers, n'est pas la plus heureuse pour la littérature"; ibidem, s. 67 i 81. Temat ten wydaje się we Francji nadal aktualny - dziennik „Le Monde” poświęcił mu niedawno cykl artykułów pod wspólnym tytułem „Zawód: pisarz. Czy można żyć z pióra?”, „Le Monde”, 7 września 2010 roku, S. $20-21$.

${ }^{33} \mathrm{Na}$ baczniejszą uwage zasługiwałyby także rozważania na temat postulowanego przy tej okazji "teatru salonowego" - a więc prywatnego, niezależnego od scen państwowych i mogącego łatwiej propagować cnoty moralne - we Francji, Włoszech (gdzie podobne sceny już istniały) i, naturalnie, w Polsce.

${ }^{34}$ „W polityce, kto nie idzie naprzód, cofa się. I Francja będzie pogrążać się w upadku, aż do chwli, gdy wzniesie swoja duszę do poziomu, jakiego żąda od niej Opatrzność Jeśli tego nie uczyni, podążając od kryzysu do kryzysu, stanie się drugą Polską. Pragniemy instruować. To jest dzisiaj najaktualniejsze słowo. Niech tak będzie. Ale czego będziemy uczyć? Jeśli powszechne objęcie nauką miałoby doprowadzić do upowszechnienia znajomości klerykalnych głupstw albo laickiego negacjonizmu, pogłębilibyśmy jedynie pustke francuskiej duszy, i bez tego jest ona ogromna. Dusza ta, poprzez podwóine zabójcze działania [swoich] sług - żywych trupów przeszłości i bezwzględnych zwolenników przyszłości, znalazła się jakby w pneumatycznej wysokociśnieniowej maszynie. Adam Mickiewicz miał głębokie poczucie niewystarczającej mocy książek w kwestii nauczania narodów". "En politique, qui n'avance pas recule; et la France descendera jusqu'à ce qu'elle remonte son âme au niveau de l'énergie que rèclame d'elle la Providence: sinon, de crise en crise, elle deviendra une seconde Pologne"; Mélanges posthumes d'Adam Mickiewicz. Vol. 1, s. XXII. Zob. też: "On veut instruire. C'est le mot d'ordre. Soit. Mais qu'enseignera-t-on? Si la généralistion obligatoire de l'instruction ne devait aboutir qu'à universaliser la connaissance de sottises cléricales ou de négations laïques, on n'aurait fait qu'augmenter le vide déjà si considérable dans l'âme française, qui, par une double action délétère des serviteurs-cadavres du passé et des fauteurs brutaux de l'avenir, a été mise comme sous une machine pneumatique à haute puissance"; ibidem, s. XXIII. I dodaje: "Adam Mickiewicz avait le sentiment profond de l'insuffisance des livres, en matière d'enseignement des nations"; ibidem, s. 150.

${ }^{35}$ Władysław nazywa sonety Petrarki „bulletins de son coeur”, podczas gdy my wiemy dzisiaj, że cykl był wielokrotnie przerabiany przez autora - w imię literackiej doskonałości, a nie biograficznej prawdy; F. Petrarca, Drobne wiersze włoskie (Rerum vulgarium fragmenta), red. P. Salwa, Gdańsk 2005, s. 8-11. Zob. też: idem, Canzoniere, red. M. Santagata, Milano 1996, s. XLVII-XLVIII i LVII-LX.

${ }^{36}$ Był to okres stosunkowo dużej jeszcze chwiejności normy ortograficznej; A. François, Histoire de la langue française cultivée, des origines à nos jours, Vol. 2, éd. A. Julie, Genè- ve 1959, s. 193-203 (L'orthographe et la prononciation). Świadomość potrzeby skodyfikowania nowej normy pojawiła się w połowie stulecia, zob. wstęp autorstwa Sainte-Beuve’a do nowego słownika Littré, wyd. 1, 1865. "La dernière édition du Dictionnaire de l'usage est de 1835 et il serait grand temps de le revoir et d'y retoucher"; cyt. za: wyd. Gall-Hachette, Paris 1968, s. 40

${ }^{37}$ R. Przybylski, Cień jaskółki. Esej o myślach Chopina, Kraków 1995, s. 85.

388 dans la dispute | tout entier à ses démonstrations $P$

9 et son front, j a d i s couvert | son front, n a g u è re couvert $P$

10 ses jous se couvrirent de roses | ses jous s e teignirent de rose $P$

11 doit $p$ re $n$ d r e une reliure en maroquin rouge | doit r e v êt $\mathrm{i} r$ une reliure en maroquin rouge $P$

33 continuait la fille | continue laje une personne $P$

40-41 il a fa it un petit tube en papier | il r o u la un petit tube en papier $P$

43 A tous prendre|A tout considérer $P$

45 il critique mes h a b it s, il persifle mes expressions, il maccuse de cruauté, | il cri-

tique mes to il e t t e s, il persifle mes expressions, il m'accuse de cruauté, $P$

${ }^{39} 82$ personne ne le sait | C'e st c e que personne ne sait $P$

84 les philosophes mariés | les philosophes dè s qu'il s s ont mariés $P$

89-90 aller danser p e n d a n t l'h i ver, répond la b e ll e fourmi | Eh bie n!

dansez maint en a nt, répond la prév oy a n te fourmi $P$

98 Qui donc e st préfér a b le | Qui fa u t-il donc p référer $P$

34-35 je n'ai pas vu le philosophe pleurer | Je n'ai ja m a is vu pleurer le Philosophe

38 Bien dit, reprit la femme de chambre /C'e st bien dit, exclama la

femme de chambre $P$

39 b i e n dit | tr è s-bi e n dit $P$

61 Ne parlez d o n c plus | Ne me parlez plus $P$

63-64 || est presque aussi pauvre | II est a c t u e I I e m e n t presque aussi pauvre $P$

$70 \mathrm{Ce}$ dialogue, que j'ai entendu à la porte d'une maison, a presque résolu $\mathrm{m}$ a q u e s t i o n | Ce dialogue, que j'ai entendu à la porte d'une maison, a presque résolu I a question suivante:Qui vaut-il mieux aimer, d'un poète ou d'un philosophe? $P$

89-90 s'il réussit à gagner | s'il réussit p a r h a s a r d à gagner $P$

4017 commeil en coupait les pages des ses doigts|Comme il se dépèchait de trancher les pages en se servant de ses doigts en guise de coupe-papier! $P$

60 c'est une vilaine chose que la prodigalité. | C'est p é r i l l u ex, la prodigalité; et quelle vilaine chose que la pauvreté! $P$

41 "[...] ayant su replier suffisamment ses ailes d'aigle pour se mouvoir en en plus étroit espace"; Mélanges posthumes d'Adam Mickiewicz, Vol. 1, s. 62.

${ }^{42}$ „Ponieważ odpowiada smakowi Francuzów, by wszystko było konwencjonalne i aby najszczersze uczucia wydawały się niemożliwe, o ile nie są kształtowane zgodnie z aktualną fantazją i moda". ("Car c'est le goût français que tout y soit conventionnel, et que les plus vrais sentiments paraissent invraisemblables s'ils ne sont point modelés sur la fantaisie qui a la vogue du jour)"; ibidem, s. 151.

${ }^{43}$ Powszechne, bezpłatne nauczanie dla wszystkich dzieci, dziewczynek i chłopców w wieku 6-13, lat wprowadzono za rządów III Republiki, w 1881 roku, w wyraźnie antyklerykalnym klimacie. Zob. najnowsze, znakomite omówienie tego zagadnienia: P. Ognier, Une école Sans Dieu? 1880-1895. Linvention d'une morale laique sous la IIle Republique, Toulou se 2008.

44 "J'aurais pu faire ici une brillante carrière, à condition d'abjurer mon principe de vie, de me tranquilliser. Les repos convient aux morts et aux heureux. Nous nous troublons forcement, et notre devoir est de troubler le monde. Je continuerai donc de suivre ma voie, avec l'espoir d'y retrouver un jour tous les gens de bonne volontè, car leur but est un"; Mélanges posthumes d'Adam Mickiewicz, Vol. 1, s. XVI-XVII. 
"daicie upiter jahes kisiles 2 "bruga fl ba ids Jpac do: jogrodu a

a MIIS?

1.

Tegoi roku, postríasa = Tem pa polsce - duoveh us ly =igk ija - kielisky 2 "or \& kithadrieisg tomoio ksigiens historgs 